\title{
A FOUCAULDIAN ANALYSIS OF THE CA PROFESSION IN SOUTH AFRICA: IMPLICATIONS FOR SOCIETY
}

\author{
J. Terblanche \\ Department of Accounting \\ University of the Western Cape \\ Cape Town, South Africa \\ e-mail: jterblanche@uwc.ac.za
}

\section{Y. Waghid}

Department of Education Policy Studies

Stellenbosch University

Stellenbosch, South Africa

e-mail: yw@sun.ac.za

\section{ABSTRACT}

Chartered accountants are often business leaders who frequently need to make decisions. Consequently, it is of importance for the fractured democratic South Africa that citizens (especially business leaders, such as chartered accountants) develop a socially just consciousness. In this article, we provide the results of an analysis of one of Michel Foucault's genealogical works, and introduce some of Foucault's views pertaining to knowledge and power. Foucault (1995) identified three disciplinary power mechanisms, namely hierarchical observation, normalising judgement, and the examination. Consequently, we used this particular Foucauldian lens to analyse the disciplinary power mechanisms evident in the CA educational landscape. Lastly, we identified the consequences for education (and therefore ultimately society) as a result of the particular power relations in the chartered accountant educational landscape and profession.

Key words: accreditation, chartered accountant, competency framework, disciplinary power mechanisms, examination, Foucault, higher education, knowledge, power, social justice

\section{INTRODUCTION}

As a young democratic state, South Africa is struggling - economic growth is insignificant; a lack of service delivery is resulting in a rise in service delivery protests; the unemployment rate is increasing; and corruption (in the private and public sector) is rampant. The country is in need of significant investments, responsible leaders and socially just democratic citizens. The chartered accountant (CA) profession has a significant role to play in changing the business 
landscape in South Africa, and as a result, also the socio-economic health of the country. This is primarily so because CAs often function as the chief financial officer (CFO), chief executive officer (CEO) or member of the board of directors in business (Barac 2013; TerraNova 2015 ${ }^{1}$ ).

Such positions and roles therefore lead to CAs often being responsible for making decisions, which affect the business directly, but possibly also the marginalised citizens as well as the environment indirectly. These decisions could involve either a profit and personal interest or a sound business resolution underpinned by a social collective perspective. It is therefore important to determine whether the CA educational landscape can cultivate or embed in CAs the appropriate competencies and skills to participate responsibly in a socially broken democratic country. Being ignorant of the particular situatedness of CAs to contribute positively to a socially just South Africa is irresponsible.

We used the work of the French philosopher, Michel Foucault, to analyse the CA educational landscape to determine the powerful relations at work and the resulting outcome for society. Mills $(2003,30)$ argues that Foucault viewed "power as a set of relations and strategies dispersed throughout a society [CA educational landscape] and enacted at every moment of interaction". Bloland $(1995,530)$ continues this argument when referring to the relationship between power in a social context and the associated knowledge in said social context, by stating, "there is no knowledge without a power question arising, and no power without knowledge". Power produces knowledge, and the knowledge that is produced increases the hold of power. For purposes of the study on which this article is based and using a Foucauldian lens, we considered whose interests are protected as a result of the dispersed power relations in the CA educational landscape, and at what cost to the collective society.

\section{THE ROUTE TO QUALIFYING AS A CA(SA)}

The CA(SA) designation is described as follows on the website of the South African Qualifications Authority (SAQA):

\footnotetext{
"The $\mathrm{CA}(\mathrm{SA})$ designation is the pre-eminent accounting, auditing, tax and financial reporting qualification in South Africa. The CA(SA) brand is recognised by business decision-makers as the most admired business designation in South Africa, as evidenced through independent market research. Holders of this designation are also prominent as business leaders in the economy of South Africa" (see SAQA 2017).
}

The path to earning this designation is spread over a minimum of seven years, and is described on the website of the South African Institute of Chartered Accountants (SAICA). SAICA is the professional accountancy body responsible for safeguarding and promoting the integrity of the 
CA profession. Several scholars have also reported on the qualification process. We only provide an abbreviated account here (see Barac 2009; Keevy and Mare 2018; Lubbe 2013; Rudman and Terblanche 2012; Strauss-Keevy 2014; Terblanche 2019; Venter and De Villiers 2013). Aspirant CAs should firstly enrol at a SAICA-accredited higher education institution (HEI) for a three-year accounting degree, followed by a postgraduate qualification to obtain a Certificate in the Theory of Accounting (CTA) (or an equivalent qualification). Only HEIs accredited by SAICA can participate in the education of potential future CAs. SAICA performs regular accreditation visits and also prescribes a competency framework $(\mathrm{CF})$, listing the minimum competencies graduates should develop during their time at the accredited HEI. Secondly, after successful completion of the relevant qualifications, prospective CAs enter into a three-year training contract at a SAICA-approved training office. Like HEIs, training offices are evaluated to determine the suitability of the particular firm (or business) to become an approved training office, and SAICA also prescribes a CF listing the competencies that should be cultivated through the training contract.

Upon leaving the HEI and before commencing with the training contract, prospective CAs write an examination that is set by SAICA. This examination is called the Initial Test of Competence (ITC) and tests whether graduates have indeed developed the required competencies through their academic qualifications. The ITC results therefore reflect the performance of HEIs to prepare their students for the ITC. After a minimum of 20 months of the training contract, trainees who were successful in the ITC, write a second examination set by SAICA to determine the suitability of the trainee to become a CA. This second examination is called the Assessment of Professional Competence (APC), and results obtained reflect the ability of the training office to present trainees with the conditions to develop appropriate professional attributes, skills and competencies associated with a qualified CA. (Before writing the APC, trainees need to complete a qualification that assesses their suitability to write the APC, facilitated by an SAICA-accredited service provider.)

In this article, we report on the higher education landscape, and our focus is therefore on SAICA, which accredits HEIs and prescribes a CF, the HEIs and their CA academics who teach on the accounting programmes, and the ITC. In the next section, we introduce the Foucauldian concepts that we used to analyse the CA educational landscape in order to consider the implications for society.

\section{FOUCAULT: ON POWER, KNOWLEDGE AND THE BIRTH OF A DISCIPLINE}

Foucault (1984) argues that his work could be grouped into the following methods for analysis, namely archaeology, genealogy and care for the self. Since the focus of this article is to report 
on an analysis of the CA educational landscape by looking into the power relations of the stakeholders, we opted to use one of Foucault's genealogical analyses as lens. Segall (2013, 486) explains the relationship between genealogy, power and knowledge as follows:

"Genealogy, as a form of understanding (or 'writing') the present, explores how institutions and systems of thoughts - regardless of their initial intent - produce and use mechanisms to discipline and govern knowledge, knowing, and the body. A genealogical methodology examines how such institutions and systems are not only a manifestation of the limits of what they can do or how they think but also examines the limitations of thought and action they help produce for those under their control."

Foucault argues that power should be "conceptualised as a chain or as a net, that is a system of relations spread throughout the society" (Mills 2003, 35). As a result, "[power] reaches into the very grain of individuals, touches their bodies and inserts itself into their actions and attitudes, their discourses, learning processes and everyday lives" (Foucault 1980a, 39). Power could therefore be perceived to be inside people, resulting in being evident in any relationship in any social context. This includes the CA educational landscape, consisting of particular role players defined by a unique relationship between the professional body and HEIs. Power could therefore result in positive or negative consequences for a particular context and society, depending on how the power is implemented and utilised as a strategy. Power is embedded in people who often seek to increase their power, which could have negative consequences (Foucault 1995). Foucault $(1995,194)$ however also argues for the positive potential within power, when stating:

"We must cease once and for all to describe the effects of power in negative terms: it 'excludes', it 'represses', it 'censors', it 'abstracts', it 'masks', it 'conceals'. In fact, power produces; it produces reality; it produces domains of objects and rituals of truth. The individual and the knowledge that may be gained of him [or her] belong to this production."

Another key dimension of Foucault's reflection on power is the essential relationship between power and knowledge or "power/knowledge" as Foucault (1980b, 235) often refers to it in order to explicate how intertwined these two concepts are. Smart $(1985,64)$ elucidates Foucault's perspectives regarding power and knowledge as follows:

"Knowledge is inextricably entwined with relations of power and advances in knowledge are associated with advances and developments in the exercise of power. Thus for Foucault there is no disinterested knowledge; knowledge and power are mutually and inextricably interdependent. A site where power is exercised is also a place at which knowledge is produced." 
Following from the above, the essence of this relationship could therefore be explained as follows: knowledge is produced through power, whilst having control over knowledge or having knowledge ultimately advances power. Waghid and Davids $(2017,25)$ concur when they say, "[p]ower, therefore, is what determines truth from fallacy. It distinguishes between that which matters and that which does not". Often there is resistance to a change in power relations, and new knowledge - which could be perceived as the truth and which could threaten a particular powerful position - is consequently silenced.

Next, we discuss the particular genealogical work of Foucault that we used as lens for analysing the CA educational landscape, namely Discipline and punish: The birth of the prison (1995).

Foucault (1995) starts this genealogical work with a juxtaposition of two different scenes depicting punishment. The work starts with a grim and brutal scene of a person who is punished for attempted murder. The year is 1757 , and the appropriate punishment is a public display of torture, consisting amongst others of moments where hot pinchers slit through human skin, where limbs are torn from the body, and the smell of burned human flesh fills the air. By contrast, in the second scene, an excerpt of the instructions for young lawbreakers is provided. It is now 1837, and the appropriated punishment consists of organised and systematic activities. The excerpt states, methodically, how the day of the inmate should be structured and what should happen every few minutes, from rising to dressing to praying and to eating. The purpose of this juxtaposition is to illustrate the significant change in the kind of punishment - from a public spectacle to controlled confinement. Foucault (1995) wants to challenge the embedded acceptance of change by raising the following critical question: what were the reasons that led to the change in the kind of punishment? For Foucault (1995), the reasons for this change are linked to a transformation in power and power relations. Smart $(1985,81)$ articulates the transformation of power and the subsequent consequences as follows:

"The shift of focus evident in penal history from the body as the immediate and direct object of the exercise of the power to punish to the 'soul' or 'knowable' man conceptualize in terms of psyche, subjectivity, personality, consciousness, and individuality represented the emergence of a new form of power and concomitant new forms of knowledge."

In Discipline and punish, Foucault (1995) elucidates the change in power and punishment by recounting three historical periods - that of public torture, that of punishment, and that of discipline. Period one - public torture - was the time of the rule of the monarchy. The focus was on inflecting bodily harm in a public spectacle that had to enforce obedience. The monarchy determined the severity of the punishment. Period two - punishment - was the time of reform. 
Petitions against the public display of torture were raised, especially by lawyers and politicians. The reformers argued that the offence was committed against society at large and not against the sovereign ruler. As a consequence, punishment that suited the crime, and not at the whim of a ruler, had to be handed out. Period three - discipline - was the time of the development of institutions. Here, the focus was on the development of the prison. A new version of power had been established and was practiced, that was associated with supervision and meticulous activities. The focus of punishment shifted from the body (referring to the public display of torture depicted earlier) to the soul of the person (referring to the youth prison where the day was subdivided into particular tasks every few minutes, as depicted earlier). Foucault (1995, 137-138) states:

"The historical moment of the disciplines was the moment when an art of the human body was born, which was directed not only at the growth of its skills, nor at the intensification of its subjection, but at the formation of a relation that in the mechanism itself makes it more obedient as it becomes more useful, and conversely."

The period of the discipline and the institution (prison) is of importance for this article as the CA profession could be seen as the discipline and SAICA as the institution. Often, the objective of discipline is to create conditions that are accepted as the norm and essential. Mills $(2003: 43)$ explains:

"Discipline consists of a concern with control which is internalised by each individual; it consists of a concern with time-keeping, self-control over one's posture and bodily functions, concentration, sublimation of immediate desires and emotions - all of these elements are the effects of disciplinary pressure and at the same time they are all actions which produce the individual as subjected to a set of procedures which come from outside of themselves but whose aim is the disciplining of the self by the self."

The question remains: how does discipline maintains its power? Foucault $(1995,170)$ posits that disciplinary power remains operative through three mechanisms, "hierarchical observation, normalizing judgement and their combination in a procedure that is specific to it, the examination". Next, we discuss each of these mechanisms.

\section{Hierarchical observation}

Foucault (1995) uses Jeremy Bentham's architectural design for a prison, namely that of the panopticon, to explain hierarchical observation. The panopticon design is explained as follows: "at the periphery, an annular building; at the centre, a tower; this tower is pierced with wide windows that open onto the inner side of the ring" (Foucault 1995, 200). Since the windows of 
the tower were made out of one-way glass, guards could gaze through the windows to observe prisoners, whilst the prisoners stared into a mirror and were unsure of the actions of those inside the tower. The impression was therefore created of perpetual observation. Foucault $(1995,201)$ argues that, as a result of this possible perpetual surveillance, the consequence of the panopticon design is:

"[T]o induce in the inmate a state of conscious and permanent visibility that assures the automatic functioning of power. So to arrange things that the surveillance is permanent in its effects, even if it is discontinuous in its action; that the perfection of power should tend to render its actual exercise unnecessary; that this architectural apparatus should be a machine for creating and sustaining a power relation independent of the person who exercises it; in short, that the inmates should be caught up in a power situation of which they are themselves the bearers."

Following from the above, prisoners could only see the tower from where the possible continuous observation was applied. As a result, the actual observer could have been anybody as the observer her- or himself remained unknown. It could therefore also even have been prisoners themselves who were responsible for the surveillance of fellow prisoners. This possibility of continuous observation resulted in prisoners acting as if they were being watched, even when there was no guard in the tower (Mills 2003, 45). The notion of the panopticon is still relevant in society, e.g. through the use of CCTV cameras or glass offices. Sheridan (2016, 3) claims, "the modern conception of panopticism is more subtle in its operation, dictating the way we behave and forcing us to conform to norms in such a way that we are never aware of the control it has over us".

\section{Normalising judgement}

As a consequence of the possible constant surveillance, the prisoners (people) conformed to specific accepted behaviour that was internalised. Behaviour outside of these accepted parameters was therefore easy to notice. Mills (2003) describes how it was mandatory for prisoners to follow particular rules, tasks and instructions to ensure the effective functioning of the prison. These rules, tasks and instructions, Mills $(2003,93)$ argues, "were internalised to such an extent that they began to seem part of the individual's personality". Foucault (1995, 182-183) recognised five different characteristics of this disciplinary power mechanism, namely:

- $\quad$ since there are accepted norms for behaviour, it is possible to compare the different actions and behaviour of individuals; 
- the accepted actions and/or behaviour earn respect and therefore become the goal;

- $\quad$ it is possible to measure and evaluate the actions and/or behaviour and to apply a hierarchical ranking system;

- $\quad$ as a result of this measurement and goals that are set, conformity is achieved; and

- $\quad$ it is easy to identify those who are operating outside of the accepted parameters.

\title{
Examination
}

The last mechanism that preserves the functioning of the disciplinary power is the examination. The examination comprises an amalgamation of hierarchical observation and normalising judgement. This mechanism is visible and practiced to differentiate between individuals, and is often associated with knowledge, the transfer of knowledge and the proof provided by student that the knowledge has been retained (Foucault 1995).

We briefly introduced the three mechanisms of disciplinary power, namely hierarchical observation, normalising judgement and examination, as described by Foucault (1995). Foucault (1995) further reasons that institutions (such as the prison or SAICA), create a disciplined and well-ordered humanity. Foucault $(1995,219)$ accordingly continues:

\footnotetext{
"The development of the disciplines marks the appearance of elementary techniques belonging to a quite different economy: mechanisms of power which, instead of proceeding by deduction, are integrated into the productive efficiency of the apparatuses from within, into the growth of this efficiency and into the use of what it produces."
}

The particular focus with the introduction of some of Foucault's views on power and knowledge was on the three mechanism of disciplinary power. Next, we report on the analysis of the CA educational landscape by using Foucault's lens pertaining to the mechanisms of disciplinary power.

\section{THE CA PROFESSION AND THE IMPLICATIONS FOR SOCIETY}

Stehr and Adolf $(2018,196)$ state:

\begin{abstract}
"The term discipline is understood in a double sense: on the one hand, it is the practice of disciplining workers and citizens; on the other hand it is the discipline-based knowledge that enables power holders to discipline workers, which means that it does not make sense to separate knowledge and power. Both are fused, one cannot be exercised without the other. There is no truth that speaks to power, only knowledge that has been created by the powerful to serve their purposes" [original emphasis].
\end{abstract}

Consequently, we had to analyse the CA educational landscape in order to determine which 
disciplinary power mechanisms are in operation, who benefits from these power mechanisms, and what the particular outcome is on society. Earlier we identified, that SAICA accredits HEIs, the CF is issued by SAICA, and the ITC is set by SAICA - three key aspects affecting the CA educational landscape. Next, we analyse these three aspects in light of the three disciplinary power mechanisms.

\section{Accreditation as a mechanism of hierarchical observation}

“'Truth' is to be understood as a system of ordered procedures for the production, regulation, distribution, circulation, and operation of statements. 'Truth' is linked in a circular relation with systems of power which produce and sustain it, and to effects of power which it induces and which extends it" (Foucault 1984, 74).

Following Foucault's argument above, it is important to be aware that the power relations in the CA profession create knowledge that is perceived as the "truth". Foucault $(1984,74)$ continues:

"There is a battle 'for truth', or at least 'around truth'-it being understood once again that by truth I do not mean 'the ensemble of truths which are to be discovered and accepted', but rather 'the ensemble of rules according to which the true and the false are separated and specific effects of power attached to the true', it being understood also that it's a matter not of a battle 'on behalf' of the truth, but of a battle about the status of truth and the economic and political role it plays."

Earlier we introduced the disciplinary power mechanism of hierarchical observation, where Foucault (1995) explains how, through the architectural design of the panopticon, the perception of constant surveillance was created. Similarly, through SAICA's practice of accreditation and the accreditation monitoring visits, HEIs perceive themselves to be constantly under observation. According to Venter and De Villiers (2013, 1258), "SAICA's monitoring visits are taken very seriously and the extensive documentation required for these visits is prepared well in advance." This is so, as the "truth" has been constituted that, without accreditation by SAICA, there is no real future for departments of Accounting ${ }^{2}$ as they will not be able to attract students (De Villiers and Venter 2010).

SAICA is not continuously present on campuses, but the sheer prospect of observation by SAICA is sufficient to influence the behaviour of departments of Accounting in order to preserve or improve their current accreditation status. In a sense, disciplinary power has been internalised, and staff in departments of Accounting ensure that actions and behaviour are in line with the acceptable expectations to preserve accreditation status. Often this internalisation of discipline is so effective that CA academics fail to be authentic from an educational 
viewpoint. CA academics naturally align closely with the profession as they are a product of this particular context and it took them a minimum of seven years to earn the right to be included in the profession by obtaining the CA(SA) designation. Verhoef and Samkin (2017) argue that the few dissonant CA academics who indeed challenge the status quo are silenced effectively not by SAICA directly, but by fellow colleagues.

In contrast, to develop by way of education in citizens, students and society, the attributes and qualities for participation so that transformational democracy becomes a possibility, requires "a coherent flexibility in their [CA academics'] approaches to their particular fields" (Gardiner 2017, 145). Gardiner (2017) explains the term "coherent flexibility" as the ability by the (CA) academic to interpret and adapt their learned teaching and learning principles, styles and approaches. This is significant, as CA academics join the academe without any educational qualifications, as they are appointed for their professional skills (Venter and De Villiers 2013). Often, the only exposure to education many CA academics get comprises the four years of their own studies. As a result, CA academics working at HEIs often do not have knowledge of elementary philosophical principles and they also have not developed the skills to implement different pedagogical practices. Hence, interpreting or adapting pedagogical practices is an unknown territory.

In this sub-section, we have argued how, through the mechanism of accreditation, the accounting profession controls the CA educational landscape, and how CA academics, aligned with the profession, participate in this disciplinary power mechanism. CA academics working at HEIs often lack theoretical and philosophical background to education and pedagogical practices.

In the next sub-section, the focus is on the prescriptive $\mathrm{CF}$, another disciplinary power mechanism.

\section{The prescriptive $\mathrm{CF}$ as a mechanism for normalising judgement}

We started this article by referring to the challenges that South Africa is facing amongst others in terms of employment, poverty, corruption, service delivery, and the need for democratic citizens with a socially responsible awareness. HEIs in South Africa should fulfil their mandate through pedagogical practices and curriculum content, and should act as role players that endeavour to reduce inequality and advance social cohesion. Earlier we stated that SAICA prescribes, by way of a CF, all the competencies that students should have developed upon leaving as graduates from accredited departments of Accounting. We also introduced Foucault's disciplinary power mechanism of "normalising judgement", which enforces conformity to accepted parameters. In light of the mandate of HEIs to contribute to society and 
the prescription of a CF by the accounting profession, we next discuss how the issue of the $\mathrm{CF}$ indeed functions as a mechanism for normalising judgement.

Cope and I'Anson $(2003,226)$ argue, "a focus on competences necessarily shifts the emphasis to professional, rather than theoretical, effectiveness". According to Lubbe (2013) as well as Venter and De Villiers (2013), this holds true for the CA educational landscape, as these authors argue that the curriculum at HEIs is, in effect, in the hands of the profession due to the prescriptive CF. SAICA rebuts such claims, as they believe they have in a sense outsourced the educational responsibilities to educational experts at HEIs, that the $\mathrm{CF}$ is merely a list of competencies, and that HEIs should develop and design their own curriculum. However, this noble rebuttal by SAICA is an illustration of a double bind. SAICA issues the CF; SAICA conducts accreditation-monitoring visits where HEIs need to display how they teach and assess the competencies; and, upon leaving HEIs, graduates write the ITC, an examination set by SAICA, which tests whether graduates have developed the required competencies as contained in the CF (Strauss-Keevy 2014). As this principal illustration of a double bind shows, it would be impossible, although necessary, for HEIs to disregard the detailed competencies prescribed by the profession through SAICA.

The content of the CF refers to technical complex matters, such as accounting and auditing standards and several pieces of legislation and regulations. In addition, the level of detail and the volume of the content make it particularly challenging for CA academics to cover all the competencies listed over the academic period (Venter and De Villiers 2013). Venter and De Villiers (2013) further report that heads of accounting departments stated during interviews that it would be impossible to teach theory of accounting or any matters not listed in the CF.

As a result, often the only teaching and learning approach that CA academics use is to explain the content of the standards and legislation. Therefore, the CA academic talks and the students listen, rather than experiencing an encounter in the classroom where the lecturer and the students deliberate about some of the underlying principles or the influence of some pieces of legislation on society. Van Romburgh $(2014,6)$ concurs, " $[\mathrm{t}]$ eaching methods [in accounting programmes] at universities often lack creativity, involve too much lecturing and dependence on textbooks".

Accordingly, Lubbe (2013) and Venter and De Villiers (2013) are of the opinion that neither are critical skills developed in the CA educational landscape, nor is the content taught in such a manner that better insight into the South African contextual reality is gained. In addition, Van Romburgh (2014) argues that accounting education has become a theoretical exercise, as the CA educational landscape is without real interaction between the business world and the students. Consequently, students struggle to conceptualise technical concepts (Rudman 
and Terblanche 2012). As a result, without deliberative encounters that cultivate critical and problem-solving skills, the possibility of transformation within students and ultimately within the wider society is significantly reduced.

HEIs have a responsibility in relation to the curriculum content and teaching and learning practices incorporated in their academic programmes. The question therefore remains: do CA academics adopt the SAICA CF as curriculum? The answer is partly associated with the ITC examination students need to write upon leaving HEIs. Venter and De Villiers $(2013,1263)$ argue that the importance of this examination results "in 'teaching-to-the-test' and in embedding and routinizing SAICA-inspired teaching institutions into the day-to-day lives of accounting academics". Since the ITC covers the content of the CF, CA academics focus on preparing students to succeed in the examination, rather than engendering deliberation skills or critical thinking. This approach has consequences for the higher education sector, as Jansen (2009, 261-262) argues,

"[T]hat the choice every school [HEI] and [every] teacher [CA academic] make about what to teach is not simply an intellectual decision about appealing knowledge or a planning decision about appropriate knowledge ... but also a political decision about valued knowledge."

CA academics are neglecting the mandate of higher education, namely that HEIs should contribute to advancing the socio-economic lived reality of the citizens. Neglecting a discussion, debate or deliberation on the construction of knowledge and whose or which power is promoted through it, is irresponsible (Segall 2013). Gray and Collison $(2002,813)$ argue that the "acceptance of the underlying political, ethical and social assumptions of accounting and finance" is not necessarily the issue, but the "unquestioned acceptance" of these political and business assumptions is a significant concern. It is possible that some of these underlying assumptions might perpetuate inequality in South Africa. Teaching approaches aligned with passing an examination, therefore acceptance of the curriculum $(\mathrm{CF})$ content without critical reflection, are however problematic. Without focusing on the why, it is near impossible to enhance a reflective capacity; critical reflection is often a prerequisite in developing a socially just awareness that could lead to ethical behaviour and decision-making (Hamilton 2007). Sikka, Haslam, Kyriacou, and Agrizzi (2007) concur by arguing that, without reflecting on the consequences of particular business decisions on society, the possibility of change will be reduced.

Boyce $(2004,578)$ asserts, "to broaden the perceived disciplinary boundaries within which they work" will lead to CA academics experiencing resistance. CA academics would perhaps rather deny "their identities - that is, they do not question accepted beliefs and ways of acting 
but simply follow them in order to avoid marginalization" (Zembylas 2003, 125). Verhoef and Samkin (2017) report that dissident voices have raised concerns in the past - about including other textbooks or a research component - but these voices have eventually been silenced through the functioning of power dispersed through the profession and particularly the CA educational landscape. Some of those dissident voices, which introduced academic research components, prescribed revolutionary textbooks, made changes to the content, but were ultimately silenced through the operation of power and 'truth', distributed through a social body.

In this sub-section, we have argued how, through the mechanism of prescribing a $\mathrm{CF}$, the accounting profession controls the curriculum content being taught at HEIs, and how CA academics, aligned with the profession, participate in this disciplinary power mechanism. Often CA academics will use teaching and learning approaches that are associated with the transfer of knowledge without any deliberation or critical reflection. In the next sub-section, the focus is on the ITC, another disciplinary power mechanism.

\section{The ITC as a mechanism of examination}

Hierarchical observation, normalising judgement and the consolidation of the two in a practice, namely the examination, are three mechanisms of disciplinary power (Foucault 1995). Accordingly, the two matters discussed above - the accreditation of HEIs by SAICA and the issuing of a descriptive CF by SAICA - reach a pinnacle in the mechanism of examination. Graduates leaving HEIs write the ITC to determine whether they have developed the required competencies as per the $\mathrm{CF}$ and, as a result, they are either deemed fit to be accepted into the profession, or not. This practice concurs with Foucault's belief that the mechanism of examination acts as a measuring tool; deciding and reaching a conclusion on an individual. Foucault (1995, 184-185) argues:

\footnotetext{
"It is not a normalizing gaze, a surveillance that makes it possible to qualify, to classify and to punish. It establishes over individuals a visibility through which one differentiates them and judges them. That is why, in all the mechanisms of discipline, the examination is highly ritualised. In it is combined the ceremony of power and the form of experiment, the deployment of force and the establishment of truth. At the heart of the procedures of discipline, it manifests the subjection of those who are perceived as objects and the objectification of those who are subjected. The superimposition of the power relations and knowledge relations assumes in the examination all its visible brilliance."
}

Foucault (1995, 187-192) explicates the disciplinary power mechanism of examination further by arguing, firstly, that the examination creates a visible outcome as result of power. Secondly, 
the examination results in a tangible document associated with one individual; and thirdly, the examination results in the presenting of an individual and her or his documented output for evaluation. These Foucauldian thoughts are relevant to the ITC that graduates write upon leaving HEIs. The ITC (a written examination) is the measurement tool, which SAICA (the profession) uses to determine whether the student can be included within the parameters of the profession. Through this practice, SAICA adheres to its responsibility to safeguard and protect the integrity of the profession and the $\mathrm{CA}(\mathrm{SA})$ designation.

Regardless of this practice of safeguarding the integrity of the profession by means of a written examination based on the content in the $\mathrm{CF}$, the risk however exists that candidates who pass the examination are either those who believe in the underlying business principles underpinning their knowledge or those who had mastered the skill to answer an examination question. McPhail (2001) is particularly concerned that students who are conceptual thinkers or who think or look through a lens of social justice, are disadvantaged in the process.

Understandably, being successful in the ITC is important for students who want to become $\mathrm{CA}(\mathrm{SA}) \mathrm{s}$. Consequently, they would like to study at an HEI that can prepare them in such a way that they would be successful in the ITC. The results obtained in the ITC, however, often dominate and influence CA academics. Venter and De Villiers (2013) argue that all the systems and structures within departments of Accounting are aligned with the ITC, and that meetings are scheduled to discuss how the ITC results can be improved, rather than to discuss scholarly activities in depth. Lubbe $(2013,88)$ concurs, "[t]he attempts by universities to maximise the performance of their students in the professional bodies' examinations result in university accounting degrees imitating professional qualifications by placing particular emphasis on learning techniques, rules and regulations."

The performance of graduates of an HEI in the ITC is important, particularly so as, firstly, the results are published widely. The results clearly indicate the performance of the students of each accredited HEI (Venter and De Villiers 2013; Lubbe 2013). The ranking and pass rate of each HEI are perceived as measurement of how good its department of Accounting is, which could result in an increase in student numbers at the institution. It therefore seems that a student's ability to pass an examination is more important for an HEI than the development of the full humanity of the student. Secondly, HEIs are financially rewarded by the profession, through a subvention scheme. The financial reward is linked to the ITC results (Venter and De Villiers 2013). CA academics consequently prioritise teaching towards the competencies contained in the CF and, as a result, assessments at HEIs imitate the ITC. Venter and De Villiers $(2013$, 1262) state, "[d]epartments fear that poor performance in the [ITC] will lead to lower student numbers, a lack of support from the profession, and reduced subvention funding." 
In this sub-section, we have argued that the prominence of the disciplinary power mechanism of the examination results in CA academics teaching towards the ITC as a goal, rather than focusing on transformational education, which results in socially responsible and emancipated citizens.

In this component of the article, we analysed the CA educational landscape and showed how the accreditation of HEIs by SAICA, the issuing of a prescriptive CF by SAICA, and the writing of the ITC can be seen as mechanisms that serve disciplinary power. These three concepts, discussed in the three sub-sections above, resemble the three mechanisms of disciplinary power for which Foucault (1995) argues, namely that of hierarchical observation, normalising judgement, and the examination.

\section{CONCLUDING REMARKS}

The aim of the study reported on in this article was to analyse the CA educational landscape by using a Foucauldian lens. As a result, it was possible to reflect on the implications for education and society due to the particular power relations that are operating in the CA profession. "[G]iven that education enables us to form a view of the world, and to change that world as a result, it has a transformative role" (Thomson and Bebbington 2004, 611). One could therefore rightly ask: is the CA educational landscape, as it is currently constituted due to the particular power relations, contributing to cultivating socially responsible and democratic citizens - in this case, $\mathrm{CA}(\mathrm{SA}) \mathrm{s}$ ? Since $\mathrm{CA}(\mathrm{SA}) \mathrm{s}$ will often be in a decision-making capacity in businesses, the failure of the higher educational landscape to truly transform students, directly affects the perpetuation of inequality and thus social cohesion in South Africa.

The analysis highlighted at least eight aspects that affect the accredited HEIs in fulfilling their mandate for true transformational education. Firstly, CA academics endeavour to align to the accreditation requirements of SAICA rather than to educational principles. Secondly, CA academics are appointed for their professional and technical skills, while they lack exposure to educational theory and diverse pedagogical practices. Thirdly, the volume and technical nature of the content listed in the $\mathrm{CF}$ result in $\mathrm{CA}$ academics adopting the $\mathrm{CF}$ as curriculum, as there is little time available to incorporate other material. Fourthly, due to the combination of the nature of the knowledge content and the lack of teaching and learning expertise, CA academics will often refer to a teaching style that merely implies that the lecturer explains technical content, whilst the students are passive listeners. A fifth aspect reflects how accounting has been watered down to a theoretical discipline with little interaction with businesses and the community since pedagogical practices mostly comprise teaching in the classroom space. In the sixth place, because of a lack of teaching and learning approaches that focus on developing 
critical skills by challenging the legislations, standards or general business principles, students accept the knowledge they receive as the truth without considering the possible implications of the underlying principles on society. The seventh aspect makes it clear that, by using an examination as guardian to determine acceptance into the profession or not, students might be coached to pass an examination, which seemingly would imply that they have obtained the required competencies. Other students, with a different view or who think conceptually or who consider the outcome of decisions on humanity, might possibly be evaluated as not suitable for entering the profession. Lastly, HEIs are driven by the ITC results and the subsequent reflection on the HEI, rather than on teaching towards the transformation and emancipation of the whole person. It is imperative that SAICA-accredited departments of Accounting fulfil their mandate - that of teaching towards the full humanity of the student for the benefit of society at large. For this to happen, change is required, particularly change that would lead to the transformation of the CA profession for the greater benefit of the fractured South African society.

\section{NOTES}

1. Received by e-mail from W. Coates (SAICA), 2 April 2016.

2. Also called Schools of Accounting or Accountancy.

\section{REFERENCES}

Barac, K. 2009. South African training officers' perceptions of the knowledge and skills requirements of entry-level trainee accountants. Meditari Accountancy Research 17(1): 19-46.

Barac, K. 2013. A Reflection on accounting within South Africa's higher education landscape. Inaugural address, University of Pretoria, Pretoria, 12 November.

Bloland, H. G. 1995. Postmodernism and higher education. The Journal of Higher Education 66(5): 521-559.

Boyce, G. 2004. Critical accounting education: Teaching and learning outside the circle. Critical Perspectives on Accounting 15: 565-586.

Cope, P. and J. I'Anson. 2003. Forms of exchange: Education, economics and the neglect of social contingency. British Journal of Educational Studies 51(3): 219-232.

De Villiers, C. and E. R. Venter. 2010. The influence of the accounting profession on the academy: A cautionary case study. South African Journal of Accounting Research 27(1): 87-124.

Foucault, M. 1980a. Prison talk. In Power/knowledge: Selected interviews and other writings 1972-197, ed. C. Gordon, 37-54. New York: Pantheon Books.

Foucault, M. 1980b. Afterword. In Power/Knowledge: Selected interviews and other writings 19721977, ed. C. Gordon, 229-260. New York: Pantheon Books.

Foucault, M. 1984. Truth and power. In The Foucault reader, edited by P. Rabinow, 51-75. New York: Pantheon Books.

Foucault, M. 1995. Discipline and punish: The birth of the prison. New York: Vintage Books.

Gardiner, M. 2017. Coercion or cohesion? Educators in a democracy. In Living together, living apart? Social cohesion in a future South Africa, ed. C. Ballentine, M. Chapman, K. Erwin and G. Maré, 145-152. Pietermaritzburg: University of KwaZulu-Natal Press.

Gray, R. and D. Collison. 2002. Can't see the wood for the trees, can't see the trees for the numbers? Accounting education, sustainability and the public interest. Critical Perspectives on Accounting 
13: 797-836.

Hamilton, S. E. 2007. Accounting for identity: Becoming a chartered accountant. PhD diss., University of Stirling.

Jansen, J. D. 2009. Knowledge in the blood: Confronting race and the apartheid past. Stanford: Stanford University Press.

Keevy, M. and D. J. Mare. 2018. Pervasive skills development for aspirant chartered accountants: Academic versus Training Programmes. Journal of Economic and Financial Sciences 11(1): 1-9.

Lubbe, I. 2013. Educating accounting professionals: Development of a theoretical framework as a language of description of accounting knowledge production and its implications for accounting academics at South African universities. South African Journal of Accounting Research 27(1): 87124.

McPhail, K. 2001. The dialectic of accounting education: From role identity to ego identity. Critical Perspectives on Accounting 12: 471-499.

Mills, S. 2003. Michel Foucault. London: Routledge Taylor \& Francis.

Rudman, R. J. and J. Terblanche. 2012. The perceived advantage of work experience as a learning tool for auditing students. Southern African Journal of Accountability and Auditing Research 13(1): $57-71$.

SAQA see South African Qualifications Authority.

South African Qualifications Authority. 2017. Professional designation: CA(SA) - Chartered accountant (South Africa). http://pbdesig.saqa.org.za/viewProfessionalDesignation.php?id=8 (Accessed 7 April 2019).

Segall, A. 2013. Revitalizing critical discourses in social education: Opportunities for a more complexified (un)knowing. Theory \& Research in Social Education 41: 476-493.

Sheridan, C. 2016. Foucault, power and the modern panopticon. Senior thesis, Trinity College.

Sikka, P., C. Haslam, O. Kyriacou, and D. Agrizzi. 2007. Professionalizing claims and the State of UK professional accounting education: Some evidence. Accounting Education 16(1): 3-21.

Smart, B. 1985. Michel Foucault. London: Travistock.

Stehr, N. and M. T. Adolf. 2018. Knowledge/Power/Resistance. Society 55(2): 193-198.

Strauss-Keevy, M. 2014. Education programmes' responsibilities regarding pervasive skills. Journal of Economic and Financial Sciences 7(2): 415-432.

Terblanche, J. 2019. Cultivating socially just responsible citizens in relation to university accounting education in South Africa. PhD diss., Stellenbosch university.

TerraNova. 2015. Change is inevitable. Progress is intentional. SAICA JSE research 2015.

Thomson, I. and J. Bebbington. 2004. It doesn't matter what you teach? Critical Perspectives on Accounting 15: 609-628.

Van Romburgh, H. 2014. Accounting education: Investigating the gap between school, university and practice. MA diss., North-West University.

Venter, E. R. and C. de Villiers. 2013. The Accounting profession's influence on academe: South African evidence. Accounting, Auditing \& Accountability Journal 26(8): 1246-1278.

Verhoef, G. and G. Samkin. 2017. The accounting profession and education: The development of disengaged scholarly activity in accounting in South Africa. Accounting, Auditing \& Accountability Journal 30(6): 1370-1398.

Waghid, Y. and N. Davids. 2017. Education, assessment, and the desire for dissonance. New York: Peter Lang.

Zembylas, M. 2003. Interrogating 'teacher identity': Emotion, resistance, and self-formation. Educational Theory 53(1): 107-127. 